\title{
PERAMALAN CURAH HUJAN DI KABUPATEN PARIGI MOUTONG MENGGUNAKAN MODEL SEASONAL AUTOREGRESSIVE INTEGRATED MOVING AVERAGE (SARIMA)
}

\author{
D. I. Purnama ${ }^{1}$ \\ 1Badan Pusat Statistik (BPS) Kabupaten Sukoharjo, Jawa Tengah \\ 1drajatindrapurnama@bps.go.id
}

\begin{abstract}
Rain is a natural phenomenon that is very important for human life. This makes predicting the amount of rainfall in an area important because it is able to support the decision-making process in various sectors of life. On the other hand, global climate change makes rainfall often unpredictable. So it is necessary to identify seasonal patterns in rainfall data so that it supports forecasting of rainfall in an area. The purpose of this research is to identify seasonal patterns and determine a good model to use to predict rainfall in Parigi Moutong Regency. The results of identifying seasonal patterns using spectral regression indicate that the rainfall data in Parigi Moutong Regency contains seasonal patterns. In addition, the best Seasonal Autoregressive Integrated Moving Average (ARIMA) model for predicting rainfall in Parigi Moutong Regency is the SARIMA model $(1,1,0)(0,1,1) 12$. This model has good forecasting accuracy which is shown by the Mean Absolute Percentage Error (MAPE) value of 12.0157 in the training data and 16.4647 in the testing data.
\end{abstract}

Keywords : Parigi Moutong Regency, Rainfall, Spectral Regression, SARIMA

\section{ABSTRAK}

Hujan merupakan fenomena alam yang sangat penting bagi kehidupan manusia. Hal ini membuat peramalan jumlah curah hujan di suatu daerah menjadi penting karena mampu mendukung proses pengambilan keputusan dalam berbagai sektor kehidupan. Dilain sisi perubahan iklim dunia membuat curah hujan seringkali susah diprediksi. Sehingga diperlukan identifikasi pola musiman pada data curah hujan sehingga mendukung peramalan curah hujan di suatu daerah. Tujuan dari penelitian ini adalah mengidentifkasi pola musiman serta menentukan model yang baik digunakan untuk meramalkan curah hujan di Kabupaten Parigi Moutong. Hasil identifikasi pola musiman mengggunakan regresi spektral menunjukkan bahwa data curah hujan di Kabupaten Parigi Moutong mengandung pola musiman. Selain itu diperoleh model Seasonal Autoregressive Integrated Moving Average (ARIMA) terbaik untuk meramalkan curah hujan di Kabupaten Parigi Moutong adalah model SARIMA $(1,1,0)(0,1,1) 12$. Model ini memiliki akurasi peramalan yang baik yang ditunjukkan dari nilai Mean Absolute Percentage Error (MAPE) sebesar 12,0157 pada data training dan 16,4647 pada data testing.

Kata kunci : Kabupaten Parigi Moutong, Curah Hujan, Regresi Spektral, SARIMA 


\section{PENDAHULUAN}

Kabupaten Parigi Moutong merupakan salah satu Kabupaten yang terletak di Provinsi Sulawesi Tengah. Kabupaten Parigi Moutong melingkupi sebagian besar dari daerah pantai timur Sulawesi Tengah dan Teluk Tomini. Wilayahnya memanjang dari ujung utara perbatasan dengan Provinsi Gorontalo sampai bagian selatan perbatasan dengan Kabupaten Poso. Secara geografis Kabupaten Parigi Moutong wilayahnya dilintasi oleh garis khatulistiwa. Menurut Tukidi (2010), wilayah yang terletak di sekitar garis khatulistiwa dicirikan dengan musim hujan yang panjang dan musim kemarau yang singkat. Hal ini terjadi karena wilayah di sekitar garis khatulistiwa adalah zona pertemuan antara dua massa udara yang berasal dari dua belahan bumi. Selain itu, wilayah yang berada bertepatan pada garis khatulistiwa umumnya memiliki curah hujan yang tinggi dan selama setahun memiliki dua kali periode hujan.

Data curah hujan merupakan data berkala yang disajikan dalam kurun waktu bulanan dan dikategorikan sebagai data deret waktu sehingga peramalan data curah hujan dapat menggunakan analisis deret waktu univariat. Analisis ini digunakan untuk menganalisis data melalui pengamatan perubahan atau pola pergerakan data dan juga mempertimbangkan data historis agar pola pergerakan data di masa lalu dapat memberikan informasi akurat dalam meramalkan pola pergerakan di masa depan. Model univariat yang umum digunakan dalam peramalan data deret waktu adalah model Autoregressive Integrated Moving Average (ARIMA) yang diperkenalkan pertama kali oleh Box dan Jenkins (1976). Model ARIMA memiliki beberapa model alternatif sesuai dengan pola dan karakteristik data, salah satunya adalah model ARIMA untuk data deret waktu yang mengandung pola musiman yang disebut model Seasonal Autoregressive Integrated Moving Average (SARIMA).

Penelitian terdahulu mengenai peramalan data curah hujan menggunakan SARIMA telah dilakukan oleh Arnita (2020). Pada penelitian tersebut dibandingkan nilai akurasi peramalan antara Naïve Model dan Model SARIMA dimana model SARIMA memiliki nilai akurasi peramalan yang lebih baik dalam meramalkan curah hujan di Kota Medan. Selain itu terdapat penelitian mengenai data deret waktu yang dilakukan oleh Darmawan (2012) yaitu pengujian pola musiman pada data deret waktu menggunakan regresi spektral. Pada penelitian tersebut mampu ditunjukkan bahwa metode regresi spektral mampu memberikan akurasi keberadaan pola musiman dan juga periode musiman pada data deret waktu secara akurat.

Berdasarkan uraian diatas maka pada penelitian ini akan menganalisa data curah hujan di Kabupaten Parigi Moutong menggunakan regresi spektral sehingga teridentifikasi keberadaan pola musiman dan periode musimannya. Selanjutnya dilakukan peramalan curah hujan di Kabupaten Parigi Moutong menggunakan model SARIMA. Diharapkan hasil peramalan model SARIMA tersebut memberikan hasil peramalan yang baik untuk meramalkan curah hujan di Kabupaten Parigi Moutong. 


\section{METODE PENELITIAN}

\subsection{Data Penelitian}

Data yang digunakan pada penelitian ini adalah data sekunder yang diperoleh dari publikasi Kabupaten Parigi Moutong Dalam Angka yang dipublikasikan oleh Badan Pusat Statistik (BPS) Kabupaten Parigi Moutong pada Tahun 2015 sampai 2021. Data dalam penelitian ini merupakan data jumlah curah hujan $(\mathrm{mm})$ di Kabupaten Parigi Moutong yang merupakan data deret waktu bulanan selama periode Januari 2014 sampai Oktober 2020 atau sebanyak 82 data deret waktu.

\subsection{Metode Analisis Data}

Metode analisis yang digunakan dalam penelitian ini adalah sebagai berikut :

1. Melakukan pembagian data training dan data testing

2. Melakukan identifikasi pola musiman pada data deret waktu

3. Melakukan identifikasi kestasioneritas data deret waktu

4. Melakukan identifikasi model SARIMA

5. Melakukan estimasi parameter model SARIMA

6. Melakukan uji signifikansi parameter SARIMA

7. Melakukan pemeriksaan diagnostik model SARIMA

8. Melakukan pemilihan model SARIMA terbaik menggunakan kriteria MAPE

Pengolahan data pada penelitian ini menggunakan bantuan Software R seri 3.6.1.

\subsection{Regresi Spektral}

Regresi spektral merupakan metode yang digunakan untuk melakukan pengujian keberadaan pola musiman pada data deret waktu (Darmawan, 2012). Metode ini digunakan untuk menelaah periodesitas tersembunyi dalam kawasan waktu. Identifikasi pola musiman dengan regresi spektral hanya bisa dilakukan pada data stasioner sehingga untuk data nonstasioner perlu menstasionerkan data menggunakan proses differencing. Persamaan regresi spektral dituliskan

$$
Z_{t}=\alpha \cos \omega t+\beta \sin \omega t+\varepsilon_{t}
$$

dengan

$$
\begin{array}{ll}
\alpha \operatorname{dan} \beta & : \text { parameter (koefisien fourier) } \\
\cos \omega t \text { dan } \sin \omega t & : \text { fungsi kontinu yang tidak berkorelasi } \\
\varepsilon_{t} & : \text { residual pada periode waktu ke- } t \\
\omega t & : \text { frekuensi fourier }
\end{array}
$$

Langkah-langkah pengujian keberadaan pola musiman menggunakan metode regresi spektral adalah

1) Menentukan data yang akan diuji musiman 
2) Persamaan $Z_{t}=\alpha \cos \omega t+\beta \sin \omega t+\varepsilon_{t}$ pada dasarnya secara esensi koefisien fourier sama dengan koefisien pada regresi standar maka bila diimplementasikan pada data dapat dituliskan menjadi persamaan fourier sebagai berikut

$$
Z_{t}=\sum_{k=0}^{n / 2}\left(a_{k} \cos \omega_{k} t+b_{k} \sin \omega_{k} t\right)
$$

dengan $\omega_{k}$ merupakan frekuensi fourier yang dapat dihitung dengan rumusan $\omega_{k}=$ $2 \pi k / n$

3) Hitung $a_{k}$ dan $b_{k}$ dengan rumusan sebagai berikut

$$
\begin{aligned}
& a_{k}= \begin{cases}\frac{1}{n} \sum_{t=1}^{n} Z_{k} \cos \omega_{k} t, & k=0 \text { dan } k=\frac{n}{2} \text { jika } n \text { genap } \\
\frac{2}{n} \sum_{t=1}^{n} Z_{k} \cos \omega_{k} t, & k=1,2, \ldots, \frac{(n-1)}{2}\end{cases} \\
& b_{k}=\frac{2}{n} \sum_{t=1}^{n} Z_{k} \sin \omega_{k} t, \quad k=1,2, \ldots, \frac{(n-1)}{2}
\end{aligned}
$$

4) Hitung nilai ordinat $I\left(\omega_{k}\right)$ dengan rumusan sebagai berikut

$$
I\left(\omega_{k}\right)= \begin{cases}n a_{0}^{2}, & k=0 \\ \frac{n}{2}\left(a_{k}^{2}+b_{k}^{2}\right), & k=1,2, \ldots, \frac{(n-1)}{2} \\ n a_{k}^{2}, & k=\frac{n}{2} \text { jika } n \text { genap }\end{cases}
$$

5) Uji keberartian terhadap masing-masing frekuensi fourier dengan hipotesis statistik sebagai berikut

a. Hipotesis

$$
\begin{aligned}
& H_{0}: \alpha=\beta=0 \text { (data tidak dipengaruhi faktor musiman) } \\
& H_{1}: \alpha \neq 0 \text { atau } \beta \neq 0 \quad \text { (data dipengaruhi faktor musiman) }
\end{aligned}
$$

b. Statistik uji

dengan

$$
T=\frac{I^{(1)}\left(\omega_{(1)}\right)}{\sum_{k=1}^{[n / 2]} I\left(\omega_{k}\right)}
$$

$$
\begin{array}{ll}
I^{(1)}\left(\omega_{(1)}\right) & \text { : ordinat maksimum dari periodogram pada frekuensi fourier } \\
\mathrm{I}\left(\omega_{\mathrm{k}}\right) & \text { : nilai ordinat periodogram pada fekuensi fourier ke- } k
\end{array}
$$

c. Kriteria uji

Tolak $H_{0}$ jika $T>g_{\alpha}$, artinya data dipengaruhi faktor musiman. Nilai $g_{\alpha}$ diperoleh dari Tabel 1.

Tabel 1 : Nilai Kritis Perbandingan Ordinat Maksimum dari periodogram dengan jumlah Periodegram $(\alpha=0,05)$

\begin{tabular}{|c|c|c|}
\hline $\mathrm{N}^{*}$ & $g_{\alpha}$ (by exact formula $)$ & $g_{\alpha}$ (by first term only) \\
\hline 5 & 0,68377 & 0,68377 \\
\hline 10 & 0,44495 & 0,44495 \\
\hline
\end{tabular}




\begin{tabular}{|l|l|l|}
\hline 15 & 0,33462 & 0,33643 \\
\hline 20 & 0,27040 & 0,27046 \\
\hline 25 & 0,22805 & 0,22813 \\
\hline 30 & 0,19784 & 0,19794 \\
\hline 35 & 0,17513 & 0,17525 \\
\hline 40 & 0,15738 & 0,15752 \\
\hline 45 & 0,14310 & 0,14324 \\
\hline 50 & 0,13135 & 0,13149 \\
\hline \multicolumn{2}{|c|}{${ }^{*} N=(n-1) / 2$ if $n$ is odd and $N=(n / 2-1)$ if $n$ is even } \\
\hline
\end{tabular}

Sumber : Darmawan, 2012.

\subsection{Kestasioneran Data Deret Waktu}

Analisis data deret waktu adalah metode yang mempelajari data deret waktu, baik dari segi teori yang menaunginya maupun untuk membuat peramalan (Rahayu, 2018). Salah satu model deret waktu adalah model deret waktu univariat. Model ini merupakan model yang mengacu pada data deret waktu yang terdiri atas satu pengamatan yang diukur selama kurun waktu tertentu, berdasarkan waktu dengan interval yang sama. Asumsi yang harus dipenuhi dalam memodelkan data runtun waktu adalah asumsi kestasioneran. Data stasioner adalah data deret waktu yang tidak memiliki tren, pola musiman serta nilai rata-rata dan variansnya konstan atau homogen dari waktu ke waktu (Cryer, 1986).

Stasioneritas ada dua yaitu stasioner dalam rata-rata dan stasioner dalam varian. Stasioner dalam rata-rata dapat dilihat dari keberadaan akar unit (unit root). Pengujian akar unit dapat dilakukan menggunakan uji Augmented Dickey Fuller (ADF). Jika data tidak stasioner dalam rata-rata maka dapat diatasi dengan proses differencing. Proses differencing dilakukan dengan cara mengurangi nilai data pada suatu periode dengan nilai data periode sebelumnya. Stasioneritas dalam varians deret waktu dapat dilihat melalui bentuk plot Box-Cox. Jika nilai lambda $(\lambda)$ melewati nilai satu pada nilai selang kepercayaanya maka sudah dapat dikatakan bahwa proses sudah stasioner dalam varians (Wijaya, 2017). Menurut Wei (2006), jika data deret waktu tidak stasioner dalam varians maka dapat dilakukan pendekatan umum untuk memperoleh stasioneritas dalam varians menggunakan transformasi Box-Cox pada data deret waktu yang dapat dituliskan sebagai

$$
T\left(Z_{t}\right)=\left\{\begin{array}{l}
\frac{Z_{t}^{\lambda}-1}{\lambda}, \text { untuk } \lambda \neq 0 \\
\ln \left(Z_{t}\right), \text { untuk } \lambda=0
\end{array}\right.
$$

dengan $\lambda$ adalah parameter transformasi. 


\subsection{Model Seasonal Autoregressive Integrated Moving Average (SARIMA).}

Model SARIMA merupakan model ARIMA yang melibatkan efek musiman. Model ARIMA sendiri merupakan model gabungan antara model Autoregressive (AR) dan model Moving Average (MA) pada data yang sudah di lakukan diferencing. Prosedur ARIMA adalah melakukan differencing pada data deret waktu nonstasioner terlebih dahulu untuk menghasilkan data deret waktu yang stasioner, dan selanjutnya melakukan proses ARMA pada data hasil differencing tersebut.

Model SARIMA terdiri dari dari bagian tidak musiman dan bagian musiman. Bagian tidak musiman dari model SARIMA merupakan model ARIMA sedangkan bagian musiman model SARIMA merupakan model AR musiman, MA musiman atau campuran AR musiman dan MA musiman.

Menurut Wei (2006), model SARIMA $(p, d, q)(P, D, Q)^{S}$ dengan $p$ adalah orde AR, $d$ adalah orde proses differencing, $q$ adalah orde MA, $P$ adalah orde $A R$ musiman, $D$ adalah orde proses differencing musiman , $Q$ adalah orde MA musiman dan $S$ adalah periode musiman secara umum dapat dituliskan sebagai

dengan

$$
\phi_{p}(B) \Phi_{P}\left(B^{S}\right)(1-B)^{d}\left(1-B^{S}\right)^{D} Z_{t}=\theta_{q}(B) \Theta_{Q}\left(B^{S}\right) \varepsilon_{t}
$$

$$
\begin{array}{ll}
\phi_{p} & : \text { parameter AR } \\
\phi_{p}(B) & : 1-\phi_{1} B-\phi_{2} B^{2}-\cdots-\phi_{p} B^{p} \\
\Phi_{P} & : \text { parameter AR musiman } \\
\Phi_{P}\left(B^{S}\right) & : 1-\Phi_{1} B^{s}-\Phi_{2} B^{2 s}-\cdots-\Phi_{P} B^{P s} \\
\theta_{q} & : \text { parameter MA } \\
\theta_{q}(B) & : 1-\theta_{1} B-\theta_{2} B^{2}-\cdots-\theta_{q} B^{q} \\
\Theta_{Q} & : \text { parameter MA musiman } \\
\Theta_{Q}(B) & : 1-\Theta_{1} B^{s}-\Theta_{2} B^{2 s}-\cdots-\Theta_{Q} B^{Q s} \\
\left(1-B^{S}\right)^{D} & : \text { differencing musiman dengan orde } D \\
(1-B)^{d} & : \text { differencing dengan orde } d \\
\varepsilon_{t} & : \text { residual yang menyebar normal dan independen } \varepsilon_{t} \sim \mathrm{N}\left(0, \sigma^{2}\right)
\end{array}
$$

\subsection{Kriteria Pemilihan Model Terbaik}

Salah satu kriteria pemilihan model terbaik adalah menggunakan nilai Mean Absolute Percentage Error (MAPE). MAPE menunjukkan gambaran ukuran ketepatan estimasi model ataupun ramalan. Nilai MAPE pada data training digunakan untuk melihat ketepatan estimasi model sedangkan nilai MAPE pada data testing menggambarkan ketepatan ramalan model. 
Tabel 2 : Kriteria MAPE

\begin{tabular}{|c|l|}
\hline Nilai MAPE $(\%)$ & \multicolumn{1}{c|}{ Kriteria } \\
\hline$<10$ & Kemampuan peramalan sangat baik \\
\hline $10-20$ & Kemampuan peramalan baik \\
\hline $20-50$ & Kemampuan peramalan cukup \\
\hline$>50$ & Kemampuan peramalan buruk \\
\hline
\end{tabular}

Sumber: Chang, Wang dan Liu dalam Qomariyah, 2017.

\section{HASIL DAN PEMBAHASAN}

\subsection{Pembagian Data Training dan Data Testing}

Tahapan awal penelitian ini adalah penentuan jumlah data training yang akan digunakan sebagai in sample dan penentuan jumlah data testing sebagai out sample pada data curah hujan Kabupaten Parigi Moutong. Banyaknya data yang digunakan pada penelitian ini adalah 82 data (Januari 2014 - Oktober 2020) dimana sebanyak 70 data merupakan data training (Januari 2014 - Oktober 2019) dan 12 data merupakan data testing (November 2019 - Oktober 2020).

\subsection{Identifikasi Pola Musiman}

Regresi Spektral merupakan salah satu metode yang digunakan untuk melihat keberadaan pola musiman pada data deret waktu. Selain itu, metode ini dapat digunakan unruk menentukan periode dari musiman. Hasil pengujian keberadaan pola musiman dan juga periode musiman menggunakan regresi spektral pada data curah hujan di Kabupaten Parigi Moutong diperoleh nilai statistik uji regresi spektral $T=0,2606539$. Menggunakan $\alpha=0,05$ dan $H_{0}$ adalah data curah hujan di Kabupaten Parigi Moutong tidak mengandung pola musiman, maka dapat disimpulkan bahwa $H_{0}$ ditolak dikarenakan $T=0,2606539$ lebih besar dari $\mathrm{g}_{\alpha}=$ 0,17513 . Hal ini berarti bahwa data curah hujan di Kabupaten Parigi Moutong mengandung pola musiman. Selanjutnya, diperoleh periode musiman data curah hujan di Kabupaten Parigi Moutong adalah 12. Artinya data curah hujan di Kabupaten Parigi Moutong mempunyai pola musiman berulang dengan periode ulangan setiap 12 bulan atau tahunan.

\subsection{Kestasioneritas Data}

Hal pertama yang dilakukan sebelum melakukan analisis data deret waktu adalah melakukan identifikasi kestasioneran data curah hujan Kabupaten Parigi Moutong. Pengujian stasioner dalam varians data deret waktu menggunakan plot Box-Cox yang ditunjukkan pada Gambar 1. Pada Gambar 1 terlihat bahwa nilai batas bawah dan batas atas lambda $(\lambda)$ plot Box-Cox tidak melalui nilai 1 sehingga dapat disimpulkan bahwa data tidak stasioner dalam varians. Selain itu pada pengujian pola musiman menunjukkan bahwa terdapat pola musiman. 
Sehingga untuk membuat data stasioner perlu dilakukan tranformasi data agar data stasioner dalam varians dan differencing musiman untuk menghilangkan pola musiman.

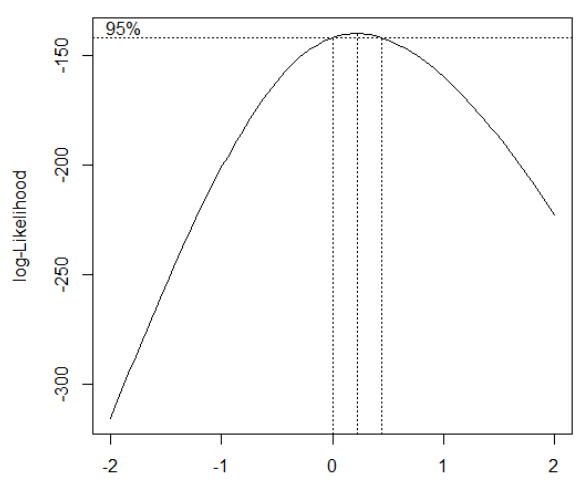

Gambar 1 : Plot Box-Cox Data Curah Hujan Kabupaten Parigi Moutong

Plot Box-Cox untuk transformasi logaritma data curah hujan di Kabupaten Parigi Moutong ditunjukkan pada Gambar 2. Terlihat bahwa data sudah stasioner karena nilai batas bawah dan batas atas melalui nilai 1 . Kemudain setelah dilakukan differencing musiman diperoleh nilai uji ADF sebesar 0,1855 lebih besar dari nilai $\alpha=0,05$ yang berarti terdapat unit root atau data tidak stasioner dalam rata-rata. Selanjutnya dilakukan differencing (biasa) untuk menstasionerkan data. Hasilnya setelah dilakukan pengujian diperoleh nilai uji ADF adalah 0,01387 (lebih kecil dari $\alpha=0,05$ ) sehingga dapat disimpulkan bahwa data sudah stasioner dalam rata-rata.

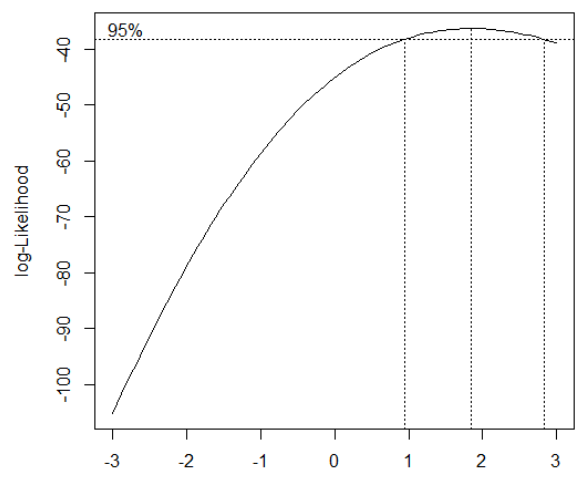

Gambar 2 : Plot Box-Cox Transformasi Data Curah Hujan Kabupaten Parigi Moutong

\subsection{Identifikasi Model SARIMA}

Identifikasi awal orde waktu pada penelitian ini dilakukan berdasarkan plot ACF dan PACF data curah hujan Kabupaten Parigi Moutong yang telah stasioner. Plot ACF dan PACF data curah hujan Kabupaten Parigi Moutong dapat dilihat pada Gambar 3. 


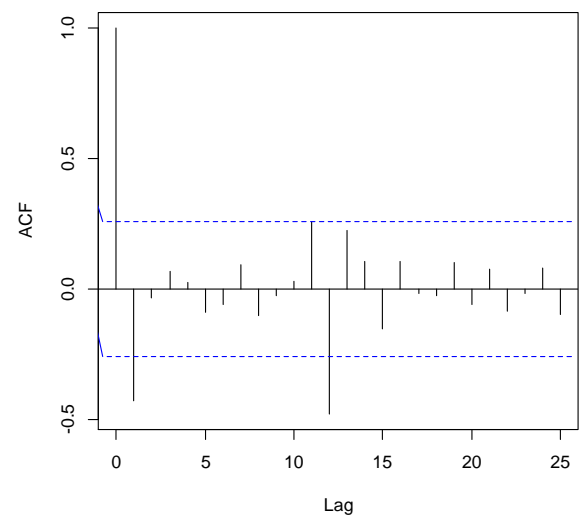

Series HUJANmus?

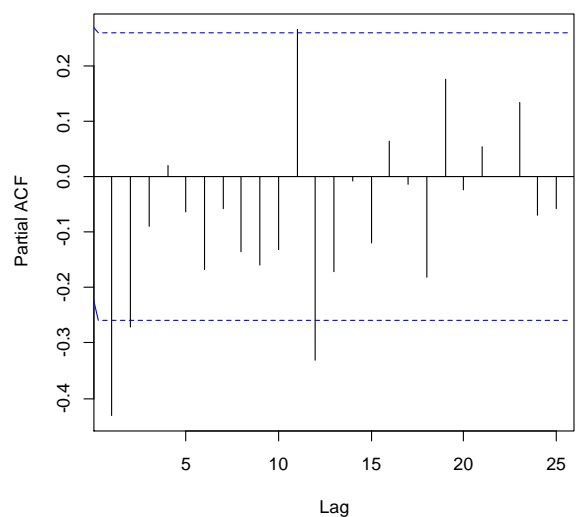

Gambar 3 : Plot ACF dan PACF data curah hujan Kabupaten Parigi Moutong

Plot ACF signifikan pada lag 1 dan 11 (komponen Moving Average) sedangkan plot PACF signifikan pada lag 1,2, dan 11 (komponen Autoregressive). Sedangkan untuk lag musiman terlihat bahwa ACF signifikan pada lag 12 (komponen Moving Average musiman). Sama halnya dengan PACF yang signifikan pada lag 12 (komponen Autoregressive musiman). Berdasarkan proses tersebut dan berdasarkan prinsip parsimony (model yang baik adalah model yang memiliki parameter yang sedikit) diperoleh beberapa kemungkinan untuk data curah hujan Kabupaten Parigi Moutong adalah $\operatorname{SARIMA}(1,1,0)(1,1,1) 12$, $\operatorname{SARIMA}(0,1,1)(1,1,1) 12, \operatorname{SARIMA}(1,1,1)(1,1,1) 12, \operatorname{SARIMA}(1,1,0)(1,1,0) 12, \operatorname{SARIMA}(0,1,1)$ $(1,1,0) 12$, SARIMA $(1,1,1)(1,1,0) 12$, SARIMA $(1,1,0)(0,1,1) 12$, $\operatorname{SARIMA}(0,1,1)(0,1,1) 12$, dan $\operatorname{SARIMA}(1,1,1)(0,1,1) 12$.

\subsection{Estimasi Parameter Model SARIMA}

Proses selanjutnya adalah melakukan estimasi parameter model SARIMA. Hasil estimasi parameter beberapa kemungkinan model SARIMA ditampilkan pada Tabel 3.

Tabel 3 : Estimasi dan Uji Signifikansi Parameter Model SARIMA

\begin{tabular}{|c|c|c|c|c|c|c|}
\hline No & Model & Parameter & $\begin{array}{l}\text { Estimasi } \\
\text { Parameter }\end{array}$ & $\begin{array}{c}\text { Standar } \\
\text { Error }\end{array}$ & thitung & Kesimpulan \\
\hline \multirow{3}{*}{1} & \multirow{3}{*}{$\begin{array}{l}\text { SARIMA } \\
(1,1,0)(1,1,1) 12\end{array}$} & AR & $-0,4018$ & 0,1301 & $-3,0884$ & Signifikan \\
\hline & & AR Musiman & $-0,3331$ & 0,1539 & $-2,1644$ & Signifikan \\
\hline & & MA Musiman & $-1,0000$ & 0,3577 & $-2,7956$ & Signifikan \\
\hline \multirow{3}{*}{2} & \multirow{3}{*}{$\begin{array}{l}\text { SARIMA } \\
(0,1,1)(1,1,1) 12\end{array}$} & MA & $-0,5054$ & 0,1455 & $-3,4735$ & Signifikan \\
\hline & & AR Musiman & $-0,2822$ & 0,1645 & $-1,7155$ & Tidak Signifikan \\
\hline & & MA Musiman & $-1,0000$ & 0,3531 & $-2,8321$ & Signifikan \\
\hline \multirow{3}{*}{3} & \multirow{3}{*}{$\begin{array}{l}\text { SARIMA } \\
(1,1,1)(1,1,1) 12\end{array}$} & AR & 0,4241 & 0,1605 & 2,6424 & Signifikan \\
\hline & & MA & $-0,9093$ & 0,1062 & $-8,5621$ & Tidak Signifikan \\
\hline & & AR Musiman & $-0,3073$ & 0,1600 & $-1,9206$ & Tidak Signifikan \\
\hline
\end{tabular}




\begin{tabular}{|c|c|c|c|c|c|c|}
\hline & & MA Musiman & $-0,9997$ & 0,3508 & $-2,8498$ & Signifikan \\
\hline \multirow{2}{*}{4} & \multirow{2}{*}{$\begin{array}{l}\text { SARIMA } \\
(1,1,0)(1,1,0) 12\end{array}$} & AR & $-0,4053$ & 0,1284 & $-3,1565$ & Signifikan \\
\hline & & AR Musiman & $-0,5791$ & 0,1124 & $-5,1521$ & Signifikan \\
\hline \multirow{2}{*}{5} & \multirow{2}{*}{$\begin{array}{l}\text { SARIMA } \\
(0,1,1)(1,1,0) 12\end{array}$} & MA & $-0,5007$ & 0,1351 & $-3,7061$ & Signifikan \\
\hline & & AR Musiman & $-0,5580$ & 0,1195 & $-4,6695$ & Signifikan \\
\hline \multirow{3}{*}{6} & \multirow{3}{*}{$\begin{array}{l}\text { SARIMA } \\
(1,1,1)(1,1,0) 12\end{array}$} & AR & 0,4433 & 0,1421 & 3,1196 & Signifikan \\
\hline & & MA & $-0,9400$ & 0,0759 & $-12,3847$ & Signifikan \\
\hline & & AR Musiman & $-0,5714$ & 0,1170 & $-4,8838$ & Signifikan \\
\hline \multirow{2}{*}{7} & \multirow{2}{*}{$\begin{array}{l}\text { SARIMA } \\
(1,1,0)(0,1,1) 12\end{array}$} & AR & $-0,4363$ & 0,1255 & $-3,4765$ & Signifikan \\
\hline & & MA Musiman & $-1,0000$ & 0,2447 & $-4,0866$ & Signifikan \\
\hline \multirow{2}{*}{8} & \multirow{2}{*}{$\begin{array}{l}\text { SARIMA } \\
(0,1,1)(0,1,1) 12\end{array}$} & MA & $-0,5625$ & 0,1343 & $-4,1884$ & Signifikan \\
\hline & & MA Musiman & $-1,0000$ & 0,2482 & $-4,0290$ & Signifikan \\
\hline \multirow{3}{*}{9} & \multirow{3}{*}{$\begin{array}{l}\text { SARIMA } \\
(1,1,1)(0,1,1) 12\end{array}$} & $A R$ & 0,7789 & 0,1509 & 5,1617 & Signifikan \\
\hline & & MA & $-0,3767$ & 0,2079 & $-1,8119$ & Tidak Signifikan \\
\hline & & MA Musiman & $-0,9999$ & 0,2846 & $-3,5134$ & Signifikan \\
\hline
\end{tabular}

\subsection{Pengujian Signifikansi Parameter SARIMA}

Pada Tabel 3 diperoleh $t$-hitung parameter model SARIMA. Berdasarkan Tabel 3 dan nilai $t$-tabel sebesar 1,9949 diperoleh enam model SARIMA yang memiliki hasil uji parsial semua parameternya signifikan antara lain model $\operatorname{SARIMA}(1,1,0)(1,1,1) 12, \operatorname{SARIMA}(1,1,0)$ $(1,1,0) 12$, SARIMA $(0,1,1)(1,1,0) 12$, SARIMA $(1,1,1)(1,1,0) 12$, SARIMA $(1,1,0)(0,1,1) 12$, dan $\operatorname{SARIMA}(0,1,1)(0,1,1) 12$.

\subsection{Pemeriksaan Diagnostik Model SARIMA}

Pemeriksaan diagnostik model bertujuan untuk memeriksa terpenuhi atau tidak asumsiasumsi 6 (enam) model SARIMA yang memenuhi uji signifikansi parameter model. Pemeriksaan diagnostik antara lain adalah uji residual white noise, dan uji asumsi residual normal.

Asumsi white noise terpenuhi jika nilai uji Portmanteaunya untuk setiap lag mempunyai nilai $\mathrm{p}$-value lebih besar dari $\alpha=0,05$. Sedangkan asumsi residual normal terpenuhi jika hasil uji Kolmogorov Smirnov memiliki nilai $\mathrm{p}$-value lebih besar dari $\alpha=0,05$. Hasil pengujian diagnostik keenam model SARIMA dapat dilihat pada Tabel 4.

Tabel 4 : Pengujian Diagnostik Model SARIMA

\begin{tabular}{|c|c|c|c|}
\hline No & Model & Uji White Noise & Uji Kenormalan Residual \\
\hline 1 & SARIMA $(1,1,0)(1,1,1) 12$ & Terpenuhi & Tidak terpenuhi \\
\hline 2 & SARIMA $(1,1,0)(1,1,0) 12$ & Terpenuhi & Terpenuhi \\
\hline 3 & SARIMA $(0,1,1)(1,1,0) 12$ & Terpenuhi & Terpenuhi \\
\hline 4 & SARIMA $(1,1,1)(1,1,0) 12$ & Terpenuhi & Tidak terpenuhi \\
\hline 5 & SARIMA $(1,1,0)(0,1,1) 12$ & Terpenuhi & Terpenuhi \\
\hline 6 & SARIMA $(0,1,1)(0,1,1) 12$ & Terpenuhi & Tidak terpenuhi \\
\hline
\end{tabular}




\subsection{Pemilihan Model SARIMA Terbaik}

Hasil pemeriksaan diagnostik model SARIMA pada Tabel 4 menunjukkan bahwa ada 3 (tiga) model yang memenuhi asumsi white noise dan residual normal. Dari ketiga model tersebut dipilih model terbaik dengan memilih model yang mempunyai nilai MAPE terkecil. Perbandingan nilai MAPE model SARIMA ditunjukkan pada Tabel 5.

Tabel 5 : Perbandingan nilai MAPE Model SARIMA

\begin{tabular}{|c|c|c|}
\hline No & Model & Nilai MAPE \\
\hline 1 & SARIMA $(1,1,0)(1,1,0) 12$ & 14,5315 \\
\hline 2 & SARIMA $(0,1,1)(1,1,0) 12$ & 14,5241 \\
\hline 3 & SARIMA $(1,1,0)(0,1,1) 12$ & 12,0157 \\
\hline
\end{tabular}

Berdasarkan Tabel 5 disimpulkan bahwa model SARIMA terbaik adalah model $\operatorname{SARIMA}(1,1,0)(0,1,1) 12$ dengan nilai MAPE sebesar 12,0157. Sesuai dengan kriteria nilai MAPE maka model SARIMA $(1,1,0)(0,1,1) 12$ memiliki kemampuan peramalan baik.

\subsection{Peramalan Curah Hujan Kabupaten Parigi Moutong Menggunakan Model $\operatorname{SARIMA}(1,1,0)(0,1,1) 12$}

Untuk melihat sejauh mana akurasi atau ketepatan model $\operatorname{SARIMA}(1,1,0)(0,1,1) 12$ dalam meramalkan curah hujan Kabupaten Parigi Moutong adalah dengan melihat nilai MAPE untuk peramalan data testing. Hasil peramalan untuk data testing diperoleh nilai MAPE sebesar 16,4647. Sehingga dapat disimpulkan bahwa model $\operatorname{SARIMA}(1,1,0)(0,1,1) 12$ memiliki kemampuan peramalan baik.

Hasil peramalan curah hujan Kabupaten Parigi Moutong pada November 2019 Oktober 2020 dapat dilihat pada Tabel 6.

Tabel 6 : Peramalan Curah Hujan Kabupaten Parigi Moutong pada November 2019 - Oktober 2020

\begin{tabular}{|c|c|c|}
\hline Bulan & Nilai Aktual $(\mathrm{mm})$ & Nilai Ramalan $(\mathrm{mm})$ \\
\hline November 2019 & 105 & 35,17 \\
\hline Desember 2019 & 95 & 15,58 \\
\hline Januari 2020 & 18 & 18,92 \\
\hline Februari 2020 & 72 & 30,08 \\
\hline Maret 2020 & 120 & 49,14 \\
\hline April 2020 & 62 & 40,04 \\
\hline Mei 2020 & 85 & 80,07 \\
\hline Juni 2020 & 352 & 98,22 \\
\hline Juli 2020 & 12 & 89,36 \\
\hline Agustus 2020 & 230 & 61,89 \\
\hline September 2020 & 95 & 47,35 \\
\hline Oktober 2020 & 36 & 59,40 \\
\hline
\end{tabular}




\section{KESIMPULAN}

Berdasarkan hasil analisis dapat disimpulkan bahwa :

1. Data curah hujan di Kabupaten Parigi Moutong pada Bulan Januari 2014 sampai Oktober 2020 mengandung pola musiman dengan periode musiman 12 bulan.

2. Model SARIMA terbaik yang digunakan untuk melakukan peramalan curah hujan di Kabupaten Parigi Moutong adalah model $\operatorname{SARIMA}(1,1,0)(0,1,1) 12$. Model ini memiliki kemampuan peramalan baik yang ditunjukkan oleh nilai MAPE sebesar 12,0157 pada data training dan 16,4647 pada data testing.

\section{DAFTAR PUSTAKA}

[1]. Arnita, Novriyana, D., dan Marpaung, F., dkk, Perbandingan Metode Single Exponential Smoothing, Naive Model,dan SARIMA untuk Peramalan Curah Hujan Di Kota Medan, Jurnal Matematika, Statistika dan Komputasi (JMSK), 2020, Vol. 17 No. 1, 117-128.

[2]. Box, G.E., and Jenkins, G.M., Time Series Analysis Forecasting and Control, California, 1976, Holden Day.

[3]. Cryer, J.D., Time Series Analysis, Boston, 1986, PWS-KENT Publishing Company.

[4]. Darmawan, G., Mulyani, S., dan Sudartianto, Pengujian Pola Musiman Pada Data Deret Waktu Dengan Menggunakan Regresi Spektral. Prosiding Seminar Nasional Statistika FMIPA Universitas Padjajaran, 2012, 63-72.

[5]. Qomariyah, L., Penerapan Model Generalized Space Time Autoregressive Integrated Moving Average (GSTARIMA) untuk Peramalan Volume Ekspor Perikanan dan Komoditas Laut Lainnya, Tesis, Bandung, 2017, Universitas Padjadjaran.

[6]. Rahayu, R.L., Penaksiran Model GSTARI dengan Metode Maximum Likelihood Estimation dan Penerapannya Pada Peramalan Harga Beras Empat Kabupaten di Jawa Barat, Tesis, Bandung, 2018, Universitas Padjadjaran.

[7]. Tukidi, Karakter Curah Hujan di Indonesia, Jurnal Geografi, 2010, Vol. 7 No. 2, 136-145.

[8]. Wei, W.W.S., Time Series Analysis : Univariate and Multivariate Methods, Second Edition, New York, 2006, Pearson Education.

[9]. Wijaya, A.S., Optimasi Parameter Model Support Vector Regression untuk Pemodelan Beban Listrik di Setiap Kota dan Kabupaten di Jawa Timur dengan Menggunakan Genetic Alghorithm dan Particle Swarm Optimization, Skripsi, Surabaya, 2017, Institut Teknologi Sepuluh Nopember. 